\title{
ANODA Pb DAN GEL ELEKTROLIT UNTUK PROPULSI KAPAL SELAM
}

\section{$\mathrm{Pb}$ ANODE AND GEL ELECTROLYTE FOR SUB MARINE PROPULSION}

\author{
Hens Saputra, Murbantan T., Abdul Ghofar, M. Rosjidi,M. Ismail, Dorit B. Islami \\ Pusat Teknologi Sumberdaya Energi dan Industri Kimia \\ Badan Pengkajian dan Penerapan Teknologi (BPPT) \\ J. M.H. Thamrin 8 Jakarta Indonesia 10340 \\ e-mail: hens.saputra@bppt.go.id
}

\begin{abstract}
Abstrak
Baterai merupakan komponen paling penting dalam sistem energi kapal selam. Hingga saat ini mayoritas kapal selam masih mengandalkan baterai jenis lead acid sebagai sumber energinya termasuk untuk propulsi karena pertimbangan faktor keamanan yang lebih baik untuk jenis baterai dengan kapasitas sangat besar, yaitu sekitar 10.000-15.000 Ah. Kendala yang terjadi untuk baterai yang menggunakan elektrolit berupa cairan antara lain timbulnya gas hidrogen pada waktu charging. Hal ini dapat mengakibatkan baterai menjadi kering dan performanya menurun. Selain itu gas hidrogen yang belebihan dapat membahayakan kapal selam itu sendiri. Pada penelitian ini dilakukan proses pembuatan anoda dan elektrolit berupa gel yang dapat mengurangi terjadinya penguapan elektrolit serta antisipasi terjadinya tumpahan elektrolit pada waktu kapal selam melakukan manuver. Sebagai elektrolit digunakan bahan berupa nanoporus anorganik MCM-41 yang dibuat dengan cara hidrotermal menggunakan Tetraethylortosilicate (TEOS) sebagai sumber silika, template organik Cethyltrimethylammonium bromide (CTAB) dan katalis $\mathrm{H}_{2} \mathrm{SO}_{4}$. Baterai gel lead acid MCM-41 dapat menghasilkan OCV sekitar 2,1 V.
\end{abstract}

Kata kunci : anoda, lead acid, baterai kapal selam, gel MCM-41, Hexagonally-ordered nanopores

\begin{abstract}
Battery is the most important component in the sub marine energy system. Up to now, majority of the sub marine are still using lead acid battery as the power source or propulsion, due to moresafe in application as very high capacity of single cell (i.e. 10.000 - 15.000 Ah). The drawbacks of aqueous based battery, which utilize liquid electrolyte, are because of having produced the hydrogen gas during charging process, in which it caused the electrolyte solution to become dry and reduced the performance of battery. In addition, that the hydrogen gas generated in the sub marine was dangerous. Therefore, the aim of this research is how to reduce or eliminate of those drawbacks by modifying kind of the liquid electrolyte by using gel electrolyte. The gel electrolyte was synthesized to reduce the evaporation of electrolyte and to avoid the leaking when submarine maneuver. The gel electrolyte was made by using inorganic nanoporous MCM-41. It was synthesized by hydrothermal method, using Tetraethylortosilicate (TEOS) as silica sources, Cethyltrimethylammonium bromide (CTAB) as organic template and $\mathrm{H}_{2} \mathrm{SO}_{4}$ as catalyst. The MCM-41 lead acid battery gave a result of OCV ca. 2,1 V.
\end{abstract}

Keywords : anode, lead acid, submarine battery, MCM-41gel, Hexagonallyordered nanopores 
Diterima (received) : 13 Juni 2017, Direvisi (reviewed) : 8 Juli 2017, Disetujui

(accepted) : 30 Juli 2017

\section{PENDAHULUAN}

Salah satu komponen yang sangat vital dalam kapal selam adalah baterai ${ }^{1}$. Dalam perkembangannya ada jenis kapal selam canggih yang menggunakan nuklir walaupun menimbulkan kontroversi tentang keamanan dan faktor keselamatan lingkungan terhadap limbah nuklir.

Baterai secara umum terdiri dari 3 komponen utama yang harus ada, yaitu anoda, katoda dan elektrolit. Anoda merupakan elektroda negatif atau sebagai donor elektron pada proses oksidasi melalui reaksi elektrokimia. Katoda merupakan elektroda positif yang mengalami reaksi reduksi pada reaksi elektrokimia. Komponen ketiga yang sangat penting adalah elektrolit yang bersifat konduktor ionik ${ }^{2}$.

Jenis baterai dan material anoda dapat mempengaruhi kapasitas dan karakteristik baterai yang dihasilkan. Energy density baterai lead acid paling rendah yaitu sekitar $0,115 \mathrm{MJ} / \mathrm{Kg}$ dibandingkan dengan dengan jenis baterai lainnya seperti $\mathrm{NiCd} 0,134$ $\mathrm{MJ} / \mathrm{Kg}$, NiMH 0, $171 \mathrm{MJ} / \mathrm{Kg}$, Li-ion 0,292 $\mathrm{MJ} / \mathrm{Kg}^{2-3)}$ Walaupun baterai lead acid memiliki energy density yang rendah, tetapi masih dapat diterima oleh konsumen karena adanya beberapa keunggulan lain, yaitu lebih aman untuk diproduksi sebagai baterai dengan kapasitas yang sangat besar seperti baterai kapal selam yang membutuhkan baterai 10.000 hingga $15.000 \mathrm{Ah} / \mathrm{sel}^{1}{ }^{1)}$ Selain itu relatif lebih aman terhadap resiko over charging dan temperatur. Energi density yang rendah tersebut dapat dijadikan sebagai nilai tambah apabila diaplikasikan pada kapal selam yang membutuhkan pemberat untuk menyelam dan stabil berada pada kedalaman tertentu.

Sejak ditemukannya struktur heksagonal MCM-41 yang sangat fantastik pada tahun 1992 oleh peneliti dari Mobil Oil Amerika Serikat ${ }^{4-5)}$, perkembangan aplikasinya sangat banyak. Karakteristik material tersebut sangat unik, antara lain memiliki luas permukaan sekitar $1000 \mathrm{~m}^{2} / \mathrm{g}$ dan volume pori sekitar $1 \mathrm{~cm} 3 / \mathrm{g}$ dengan distribusi ukuran pori yang sempit ${ }^{4-7)}$ yang menunjukkan sangat homogen. Berdasarkan penelitian sebelumnya diketahui bahwa dalam kondisi alkalin, material MCM-41 berubah menjadi ge $^{5)}$. Begitu juga pada kondisi asam.
Pada penelitian ini dilakukan pembuatan dan karakterisasi anoda $\mathrm{Pb}$ dan elektrolit gel MCM-41 serta pengujian sebagai sel elektrokimia. Karakterisasi material menggunakan XRD untuk mempelajari struktur gel MCM-41 dan anoda Pb. Dilakukan pula analisis porositas gel MCM41 serta karakteristik mekanik yang merupakan informasi penting apabila diaplikasikan pada baterai kapal selam. Dilakukan pula uji open circuit voltage (OCV).

\section{BAHAN DAN METODE}

\section{Pembuatan Anoda $\mathrm{Pb}$}

Anoda $\mathrm{Pb}$ dapat dibuat dengan menggunakan metode elektrodeposisi ${ }^{8-9}$ untuk mendapatkan kemurnian yang tinggi dan luas permukaan yang lebih baik. Salah satu kekurangan dari pelat $\mathrm{Pb}$ biasa adalah densitas dan luas permukaan. Larutan elektrolit yang digunakan adalah asam sulfat. Sebagai substrat digunakan pelat tembaga dengan luas ${ }^{10)}$. Arus yang digunakan pada proses elektrodeposisi adalah sekitar 100 $\mathrm{mA} / \mathrm{cm}^{2}$. Elektrodeposisi dilakukan selama 3 jam.

\section{Pembuatan Elektrolit Gel MCM-41}

Membran MCM-41 yang digunakan sebagai separator sekaligus menjadi elektrolit berbentuk gel yang memisahkan antara anoda dan katoda. Nanoporus MCM41 bersifat hidrofilik, sehingga dapat berperan sebagai elektrolit karena kemampuannya menyerap larutan elektrolit. Membaran MCM-41 pada anoda Pb dibuat dengan cara dip coating ${ }^{5,11)}$. Larutan induk yang digunakan untuk membuat membran MCM-41 adalah terdiri dari surfaktan cethyltrimethyl-ammonium bromide $\mathrm{C}_{16} \mathrm{H}_{33}\left(\mathrm{CH}_{3}\right)_{3} \mathrm{NBr}$ (C16TAB) yang berperan sebagai template organic, $\mathrm{HCl}$ sebagai katalisator dan pelarut aquades serta ethanol. Sumber silica yang digunakan adalah tetraethylortosilicate (TEOS). Adapun komposisi larutan induk tersebut adalah perbandingan molar sebagai berikut: 0.05 CTAB, 1.0 TEOS, $0.5 \mathrm{HCl}, 25 \mathrm{C}_{2} \mathrm{H}_{5} \mathrm{OH}$ dan $75 \mathrm{H}_{2} \mathrm{O}$. Semua bahan dicampur dan diaduk dengan kecepatan $200 \mathrm{rpm}$ pada temperatur $30^{\circ} \mathrm{C}$ selama 1 jam. Selanjutnya dilakukan dip coating pada pelat anoda. Untuk lebih jelasnya dapat dilihat pada Gambar 1. 
CTAB, Aquades, Ethanol, $\mathrm{HCl}$, TEOS

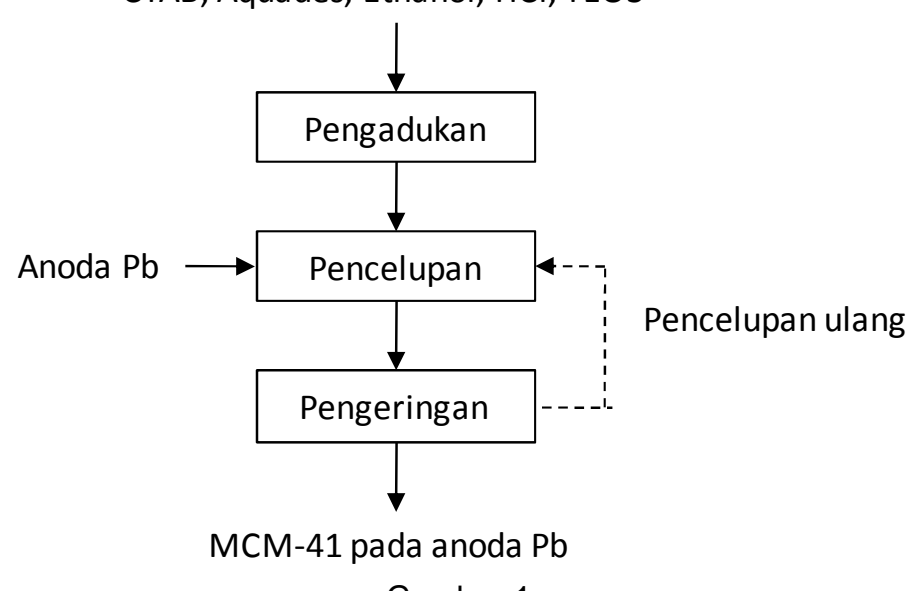

Gambar 1.

Blok diagram proses pembuatan membrane MCM-41 pada anoda $\mathrm{Pb}$

\section{Analisis dan Karakterisasi}

Anoda $\mathrm{Pb}$ dianalisis komposisinya dan grain boundary menggunakan mikroskop optik. Observasi struktur mikro dilakukan menggunakan Scanning Electron Microscope JED-2100, JEOL Co. Ltd. Adapun identifikasi struktur MCM-41 dilakukan menggunakan X-ray diffraction (XRD, $\mathrm{Cu} \mathrm{K} \alpha$ radiation). Karakteristik pori dipelajari mengunakan metode physisorption (Adsorpsi-desorpsi isothermal) Quantachrome AUTOSORB-1. Nitrogen divariasikan tekanan uap relatifnya dari 0 hingga 1. Berdasarkan data yang dihasilkan, dapat digunakan untuk menganalisis distribusi ukuran pori. Lebih lanjut membran MCM-41 yang berbah menjadi gel dianalisis sifat mekaniknya. Dilakukan pula uji open circuit voltage (OCV) selama 24 jam menggunakan Eco Chemie (The Netherland) Autolab Galvanostat Potentiostat.

\section{HASIL DAN PEMBAHASAN}

Berdasarkan pengamatan mikroskopik anoda $\mathrm{Pb}$ yang dihasilkan dapat diketahui bahwa butir $\mathrm{Pb}$ yang relatif seragam dengan ukuran rata-rata $5 \mu \mathrm{m}$ (Gambar 2).

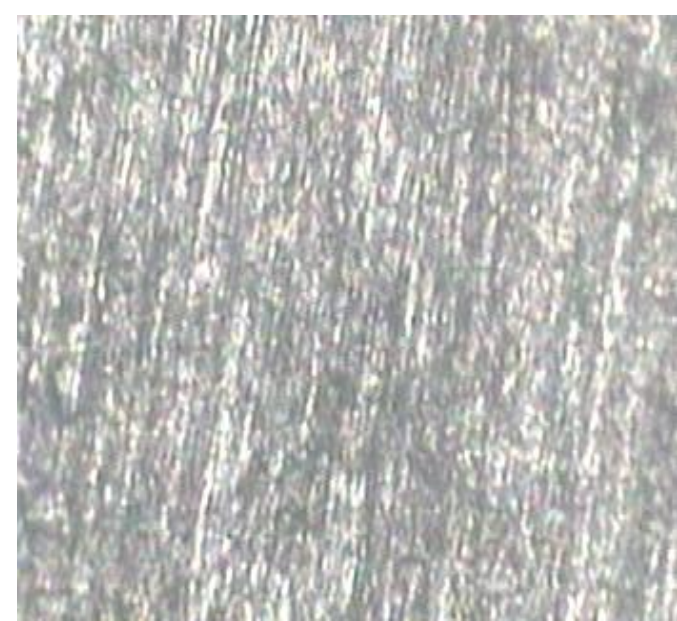

Gambar 2.

Foto mikroskopik anoda $\mathrm{Pb}$

Hasil pengamatan mikroskopik ini diperkuat dengan data observasi Scanning Electron Microscope (SEM) seperti yang terlihat pada Gambar 3.

Struktur heksagonal MCM-41 dapat diidentifikasi menggunakan XRD sebagaimana terlihat pada Gambar 4, menunjukkan adanya struktur heksagonal. Yang menjadi cirri khas struktur MCM-41 adalah adanya 4 puncak pada grafik XRD tersebut, secara lebih detil dapat dilihat pada Tabel 1. 


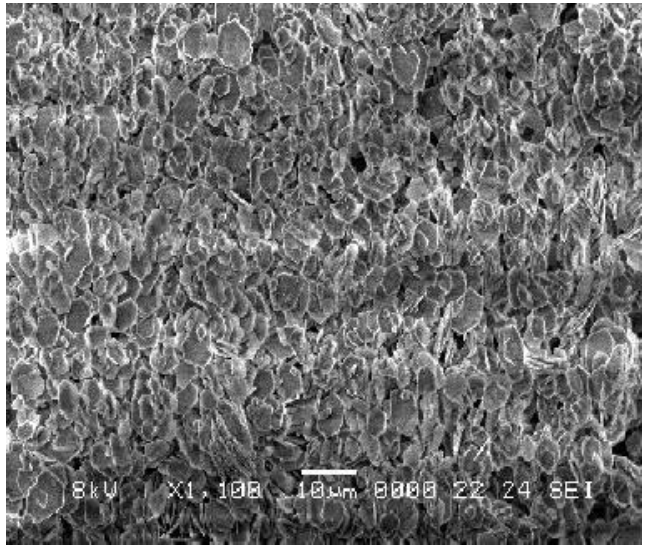

Gambar 3.

Foto SEM anoda yang dihasilkan

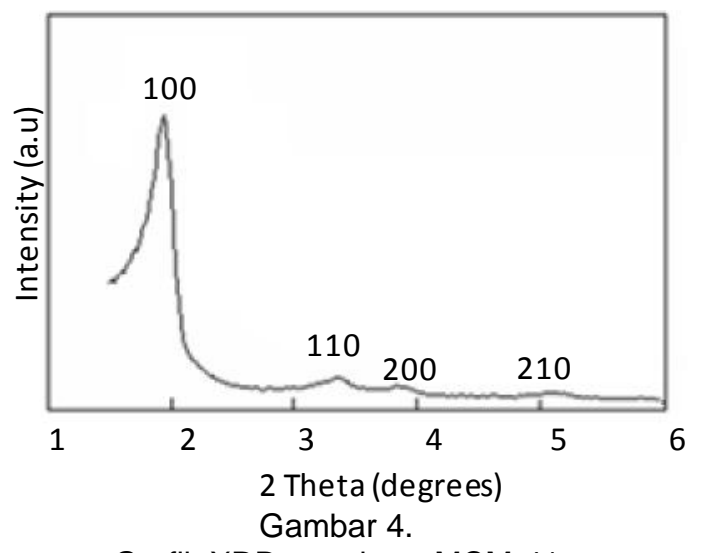

Grafik XRD membran MCM-41
Tabel 1.

Ciri khas struktur MCM-41 pada grafik XRD

\begin{tabular}{cc}
\hline $\mathrm{hkl}$ & $\mathrm{d}(\AA)$ \\
\hline 100 & 39.8 \\
110 & 22.9 \\
200 & 19.8 \\
210 & 14.9 \\
\hline
\end{tabular}

Hasil analisis adsorpsi-desorpsi isothermal menggunakan nitrogen pada $44 \mathrm{~K}$ dapat dilihat pada Gambar 5. Berdasarakan Gambar 5 dapat diketahui bahwa kenaikan tekanan uap relatif (P/P0) menyebabkan peningkatan volume nitrogen yang terserap oleh MCM-41. Kenaikan yang signifikan terjadi pada daerah tekanan uap relatif 0,4 hingga 0,6 mengindikasikan adanya pori yang berukuran meso ${ }^{12}$. Terlihat pula adanya kenaikan grafik adsorpsi nitrogen pada daerah tekanan uap relatif $0,9-1$ menunjukkan adanya pori yang berukuran makro. Terlihat jelas adanya hysteresis adalah menggambarkan ukuran pori yang tidak sama antara pada bagian luar dan bagian dalamnya. Sehingga proses desorpsi menjadi lebih lambat, karena masih ada nitrogen yang terjebak di dalam pori yang berbentuk seperti gua. Berdasarkan data physisorption maka dapat dihitung luas permukaan spesifik (BET) material MCM-41 yang dihasilkan adalah $1300 \mathrm{~m}^{2} / \mathrm{g}$ dan volume pori $1,08 \mathrm{~cm}^{3} / \mathrm{g}$. Distribusi ukuran pori dihitung menggunakan metode BJH, hasilnya dapat dilihat pada Gambar 6 .

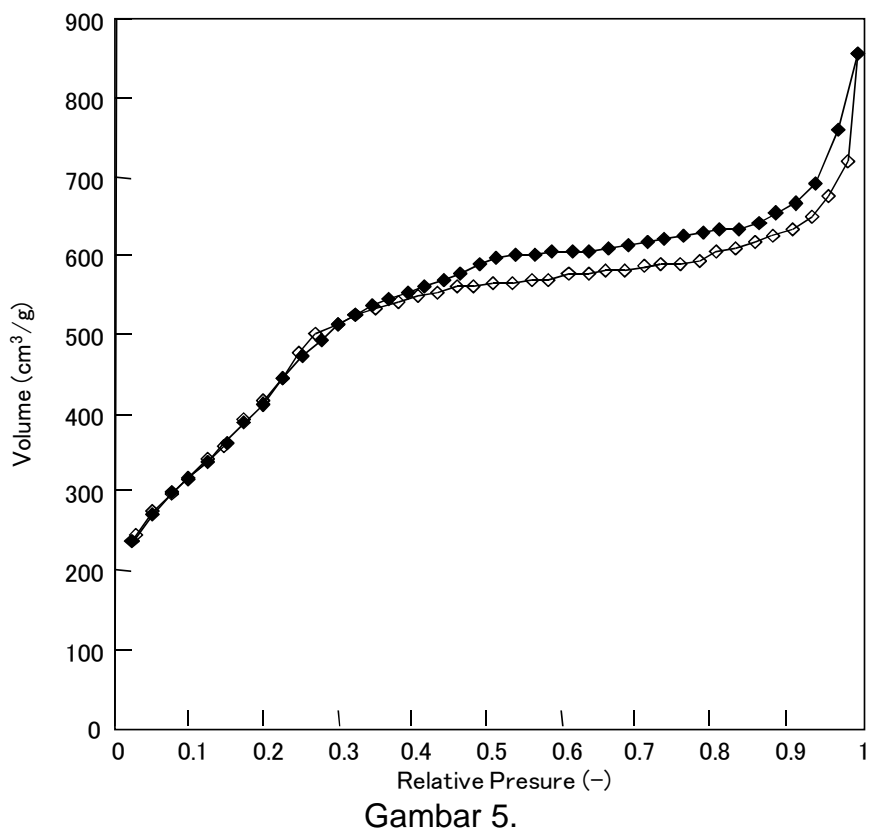

Adsorpsi-desorpsi isothermal pada MCM-41 


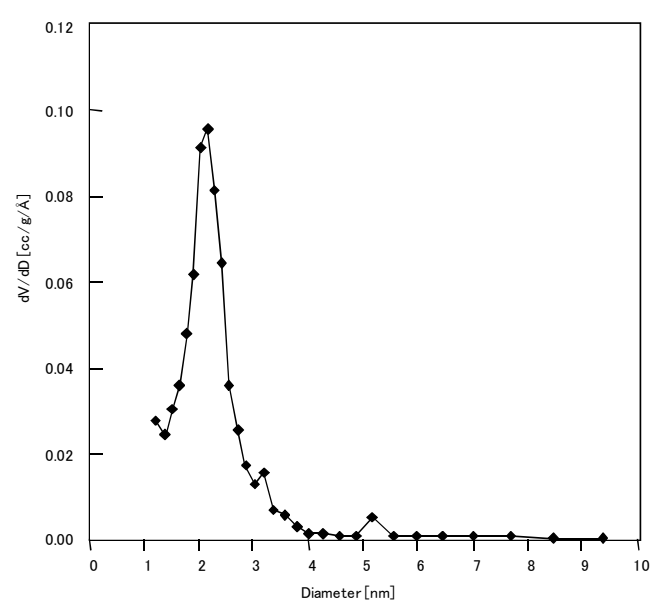

Gambar 6. Distribusi ukuran pori material MCM-41 yang dihasilkan
Berdasarkan Gambar 6. Terlihat bahwa ukuran pori dari material MCM-41 yagn dihasilkan cukup homogen. Kondisi ini didukung oleh distribusi ukuran pori yang sempit dengan ukuran pori rata-rata sekitar 2,1 nm. Ukuran ini mendukung fungsinya sebagai elektrolit yang dapat dilalui oleh ion $\mathrm{SO}_{4}{ }^{2-}$.

Sel $\mathrm{Pb}-\mathrm{MCM}-41$ dengan elektrolit asam sulfat $\left(\mathrm{H}_{2} \mathrm{SO}_{4}\right)$ dengan konsentrasi $37 \%$ atau SPGR 1,28 menghasilkan open circuit voltage (OCV) yang relatif stabil dalam pengamatan selama 24 jam, yaitu sebesar 2,1 Volt seperti ditampilkan pada Gambar 7. Hasil analisis tersebut membuktikan bahwa sel Pb-MCM-41 dapat bekerja dengan baik. Apabila separator MCM-41 terlalu tipis maka terjadi hubungan singkat yang mengakibatkan voltage menjadi nol.

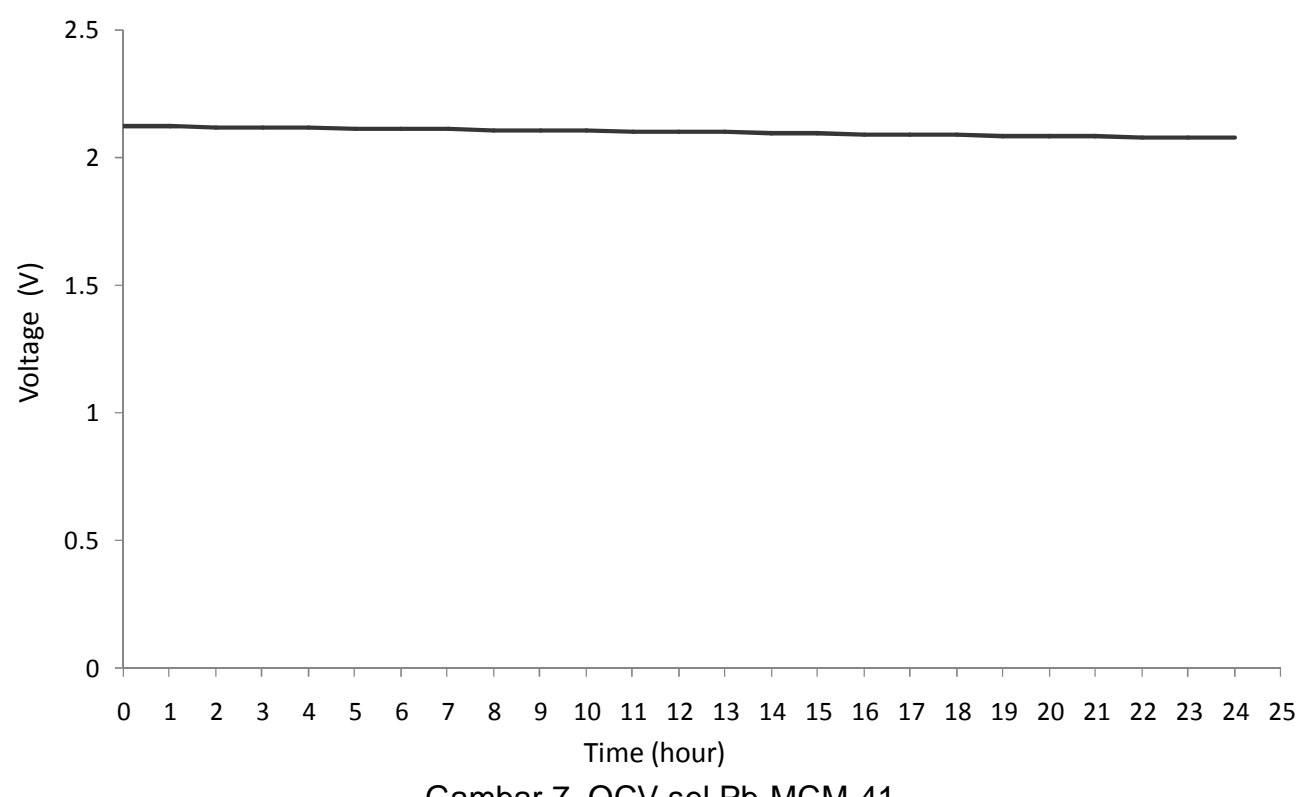

\section{SIMPULAN}

Elektroda $\mathrm{Pb}$ dapat dibuat menggunakan elektrodeposisi dengan arus $100 \mathrm{~mA} / \mathrm{cm} 2$, selama 3 jam, menghasilkan tebal sekitar $200 \mu \mathrm{m}$. Material MCM-41 dapat berfungsi sebagai gel elektrolit baterai lead acid. Sistem sel Pb-MCM-41 dapat menghasilkan OCV sekitar 2,1 Volt. Merupakan potensi untuk diaplikasikan sebagai baterai untuk propulsi kapal selam. Karakteristik gel elektrolit MCM-41 yang menggunakan asam sulfat dengan konsentrasi sekitar 37\%

\section{UCAPAN TERIMA KASIH}

Riset ini terlaksana dengan menggunakan dana Insinas 2016 dari Kementerian Riset, Teknologi dan Pendidikan Tinggi Republik Indonesia.

\section{DAFTAR PUSTAKA}

1. McGuinness, M. and B. Benjamin, Submarine Lead-Acid Battery Performance, Australian Submarine Corp., 2003

2. Linden, D., Handbook of Batteries, 3rd edition, Mc Graw Hill, New York, 2001

3. Deveau, J., C. White and Lukas G. Swan, Lead-acid battery response to various formation levels for off-grid solar and conventional applications, 
Sustainable Energy Technologies and Assessments, Vol 11, September 2015m 1-10

4. Kresge, C.T., M.E. Leonowicz, W.J. Roth, J.C. Vartuli and J.S. Beck, Nature, 359 (1992) 710.

5. Hens, S., R. Othman, A.G.E. Sutjipto and $R$. Muhida, MCM-41 as a new separator material for electrochemical cell: Application in zinc-air system, J. Mem. Sci., 367, 2011 152-157

6. Fei Qi, Wei Chu and Bingbing Xu, Catalytic degradation of caffeine in aqueous solutions by cobalt-MCM- 41 activation of peroxymonosulfate, Applied Catalysis B. Environmental, Volumes 134-135, 2013, 324-332

7. Vernal, C., M. Mesa, M. Jaber, J. Louis Guth, L. Sierra, Contribution to the understanding of the formation mechanism of bimodal mesoporous MCM-41 type silica with large defect, Microporous and Mesoporous Materials, volume 153, 2012, 217-226

8. Yongping L., C. Dong, Xiaogang Li and Yang Tian, A photoelectrochemical sensor for lead ion through electrodeposition of $\mathrm{PbS}$ nanoparticles onto $\mathrm{TiO}_{2}$ nanotubes, Journal of Electroanalytical Chemistry, V. 759 Part $1,2015,51-54$
9. Mashkouri, N. N., M. Eidizadeh, S. Seidi, E. Ghasemi and R. Alzadeh, Developing electrodeposistion techniques for preconcentration of ultratraces of $\mathrm{Ni}, \mathrm{Cr}$ and $\mathrm{Pb}$ prior to arcatomic emission, Microchemical Journal Vol 93, Issue 2, 2009, 159-163

10. Wang, L., Hao Zhang, Gaoping Cao, Wenfeng Zhang, H. Zhao and Y. Yang, Effect of activated carbon surface functional groups on nano-lead electrodeposition and hydrogen evolution and its application in leadcarbon batteries, Electrochimica Acta, V. $186,2015,262-271$

11. Wang, B., Tao Zhu, Lizhen Huang, Teck Lip Dexter Tam, Zequn Cui, Jinggiang Ding and Lifeng Chi Addressable growth of oriented organic semiconductor ultra-thin films on hydrophobic surface by direct dipcoating, Organic Electronics, V. 24, 2015, 170-175

12. Zhang, Z., and Zhenghong Yang, Theoretical and practical discussion of measurement accuracy for physisorption with micro- and mesoporous materials, Chinese Journal of Catalysis, V.34 Issue 10, 2013, 17971810 